\title{
Durability of the earth mortar: Physico-chemical and mineralogical characterization for the reduction of the capillary rise
}

\section{Durabilité du mortier en terre: Caractérisation physico-chimique et minéralogique pour la réduction de la remontée capillaire}

\author{
A.Ammari ${ }^{1}$, K. Bouassria ${ }^{2}$, N. Zakham ${ }^{1}$, M. Cherraj ${ }^{1}$, H. Bouabid ${ }^{1}$, S. Charif D'ouazzane ${ }^{3}$ \\ ${ }^{1}$ LMM, Dept. of physics, Mohammed V University, Rabat, Morocco \\ ${ }^{2}$ LSIMO, Dept. of physics, Ibn Tofail University, Kenitra, Morocco \\ ${ }^{3}$ LMTM, National School of Mineral Rabat, Morocco \\ 1abdelmalek09@gmail.com
}

\begin{abstract}
The stabilization of the earth material in the fields related to the earthen construction, in compliance with the standards in force, allows strong results of strength and durability. The chemical and mineralogical elements play an important role, in the presence of an 'optimum' cement dosage, to strengthen the ties between the clays and the grains of the earth.. This approach targets the search for better performances in the use of natural materials resource in an ecoresponsible habitat. This study presents the experimental results of the four techniques of mineralogical and chemical analysis on mortar specimens obtained from earth of the city of Fez. The results of the uni-axial compressive tests of the cylindrical specimens for this earth, associated by various percentages $0 \%, 4 \%, 7 \%$ and $10 \%$ by weight of cement, make it possible to analyze the effect of the mineralogical and chemical elements on the mechanical properties, namely Young's modulus, compressive strength and limiting deformation. However, we determine the water absorption coefficient of the mortar for different cement dosages in order to optimize the durability of the mortar against bad weather, rain and / or very wet climates. In the earth mortar of $\mathrm{Fez}$, the strong presence of calcite (CaCO3), quartz $\mathrm{SiO} 2$ and dolomite $\mathrm{CaMg}$ (CO3)2 amplifies the improvement of the behavior of the material by the addition of cement. In fact, this strong presence of calcite stabilized the clay by cementing quartz and the cement matrix to strengthen the ties between the grains of the earth. In addition, with respect to the capillary rise, the water absorption decreases with the addition of cement. We also note that the evolution of the mechanical properties is of no importance except in the interval [4 to 7\%] which represents the zone of effect for cement stabilization and which houses the optimum technicoeconomic cement dosing.
\end{abstract}

Résumé. La stabilisation du matériau terre crue dans les domaines liés à la construction en terre, dans le respect des normes en vigueur, permet des résultats de résistance mécanique et de durabilité forts probants. Les éléments chimiques et minéralogiques y jouent un rôle déterminant et permettent, en présence d'un dosage 'optimal' du ciment, de renforcer les liens entre les argiles et les grains de la terre. Ainsi, la connaissance de la nature de la terre crue à utiliser dans la construction, par l'identification scientifique de ses composantes, est incontournable à cet effet. Cette démarche cible la recherche de performances meilleures dans l'utilisation des matériaux naturels et bio ressourcés au niveau d'un habitat éco responsable. Notre recherche présente les résultats expérimentaux des quatre techniques des analyses minéralogiques et chimiques sur des éprouvettes de mortier obtenues à partir d'une terre de la ville de Fès par la diffraction des rayons X, l'Infrarouge, le Microscope électronique à balayage et la fluorescence X. Les résultats des essais de compression uni-axiale des éprouvettes cylindriques de cette terre associée aux différents pourcentages $0 \%$, $4 \%, 7 \%$ et $10 \%$ en poids de ciment, permettent d'analyser l'effet des éléments minéralogiques et chimiques sur les caractéristiques mécaniques à savoir le module d'Young, la résistance à la compression et la déformation limite. De plus, nous déterminons le coefficient d'absorption de l'eau du mortier pour différents dosages en ciment afin d'optimiser la durabilité du mortier face aux intempéries, à la pluie et/ou des climats très humides. Dans le mortier de terre de Fès, on constate que la présence forte de la calcite $\left(\mathrm{CaCO}_{3}\right)$, du quartz $\mathrm{SiO}_{2}$ et de la dolomie $\mathrm{CaMg}\left(\mathrm{CO}_{3}\right) 2$ amplifie l'amélioration du comportement du matériau par l'ajout de ciment. En effet, cette forte présence de la calcite a stabilisé l'argile par la cimentation de quartz et la matrice de ciment à renforcer les liens entre les grains de la terre. Par ailleurs, en ce qui concerne la remontée capillaire, l'absorption d'eau diminue avec l'ajout du ciment. Nous notons aussi que l'évolution des caractéristiques mécaniques n'a pas d'importance que dans l'intervalle [4 à 7\%] qui représente la zone d'effet pour la stabilisation en ciment et qui abrite l'optimum technico-économique du dosage en ciment. 


\section{INTRODUCTION}

Local materials used in construction and civil engineering for the construction of habitats in southern countries represent low environmental and economic costs. The determination of their physicochemical characteristics as well as their control are essential tasks for the good functioning, durability at each stage of the realization of a structure. To reinforce these characteristics, the stabilization of the soil by adjuvants is applied in a systematic manner. To master this practice, we propose a mineralogical and chemical characterization of the earth used based on analysis and mechanical tests [1, 2, 3] and an evaluation of the mechanical characteristics of the earth mortar in two dry and wet cases [4, 5, 6, 15]. We worked with the cement-stabilized earth mortar to determine its mechanical characteristics by simple compression tests on cylindrical specimens in both cases and by the capillary absorption ties to determine the water absorption coefficient $[6,19]$.

This study also determines the area interval of the technico-economic optimum (OTE) [4, 20].

\section{Material and methods}

The soil used in this study comes from the region of Fez referenced by $\mathbf{F}$. The following table summarizes the granular fraction of this earth:

Table 1. The granular fraction of the earth of Fez

\begin{tabular}{|c|c|c|c|c|}
\hline \multirow{4}{*}{ Earth F } & \multicolumn{4}{|c|}{ Granular fraction (\%) } \\
\cline { 2 - 5 } & $\begin{array}{c}\text { Coarse } \\
\text { sands }\end{array}$ & Fine sand & Silt & clays \\
\cline { 2 - 5 } & 41,67 & 30,55 & 16,67 & 11,11 \\
\hline
\end{tabular}

The identification of the earth is completed by the analysis of the clay part to define its states of consistency known as Atterberg limits: liquidity limit (WL), plasticity limit (WP) and plasticity index IP $=$ WL - WP. These limits are given in Table 2. This table also includes the activity coefficient $\mathrm{Ca}$ and the specific surface area $\mathrm{Sa}$.

Table 2. Limits of soil consistency F

\begin{tabular}{|c|l|l|l|c|l|}
\hline \multirow{2}{*}{$\begin{array}{c}\text { Earth } \\
\text { F }\end{array}$} & $\mathbf{W p}(\boldsymbol{\%})$ & $\mathbf{W L}(\boldsymbol{\%})$ & $\mathbf{I P}(\boldsymbol{\%})$ & $\mathbf{C a}$ & $\mathbf{S a}(\mathbf{m} \mathbf{2} / \mathbf{g})$ \\
\cline { 2 - 6 } & 25,32 & 35,58 & 10,26 & 1,28 & 48,93 \\
\hline
\end{tabular}

According to table 2, we conclude the earth $\mathrm{F}$ is active.

\section{Results of mineralogical and chemical analyzes}

The chemical and mineralogical of earthen mortar elements are analyzed to determine the proportions of the elements, by four analysis techniques, namely: X-ray diffraction, Infrared, Scanning Electron Microscope and $\mathrm{X}$-ray fluorescence.

\subsection{X-ray diffraction (DRX)}

The analysis by X-ray diffraction of the earth $\mathrm{F}$ shows that it is formed mainly of calcite $\mathrm{CaCO} 3$, Of quartz $\mathrm{SiO} 2$ And dolomite $\mathrm{CaMg}(\mathrm{CO} 3) 2$ (Figure 1).

The addition of cement to the mortar increases the percentage of calcite and the presence of Silicate Aluminum but in small proportions only is due to the presence of alumina and silica in the soil used and the cement added (Figures 2, 3 et 4).

The presence of calcite and the absence of portlandite show that the binders are fully carbonated. According to Mertens et al. [18] quartz is not a binder and it forms a part of the fine sand fraction of the aggregate.

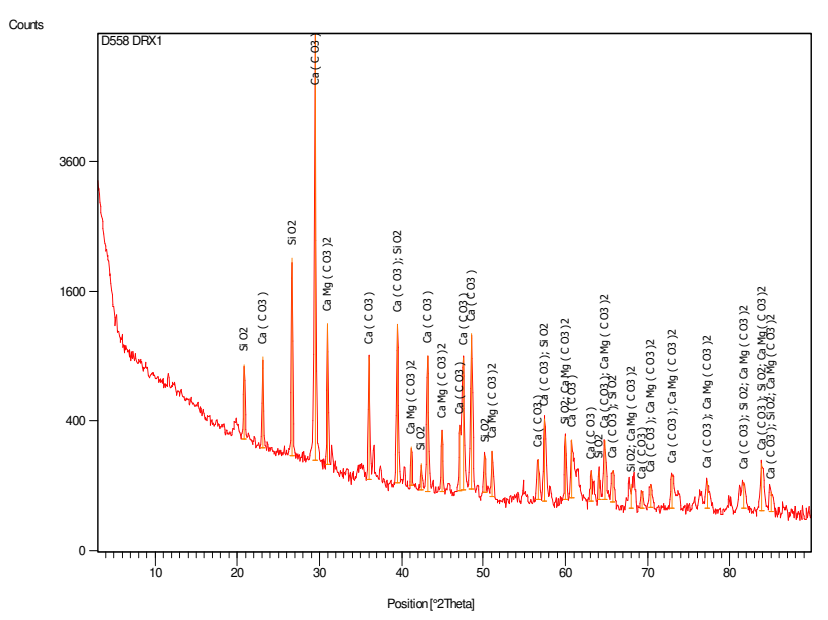

Fig. 1.: X-Ray Diffraction Spectrum of earth

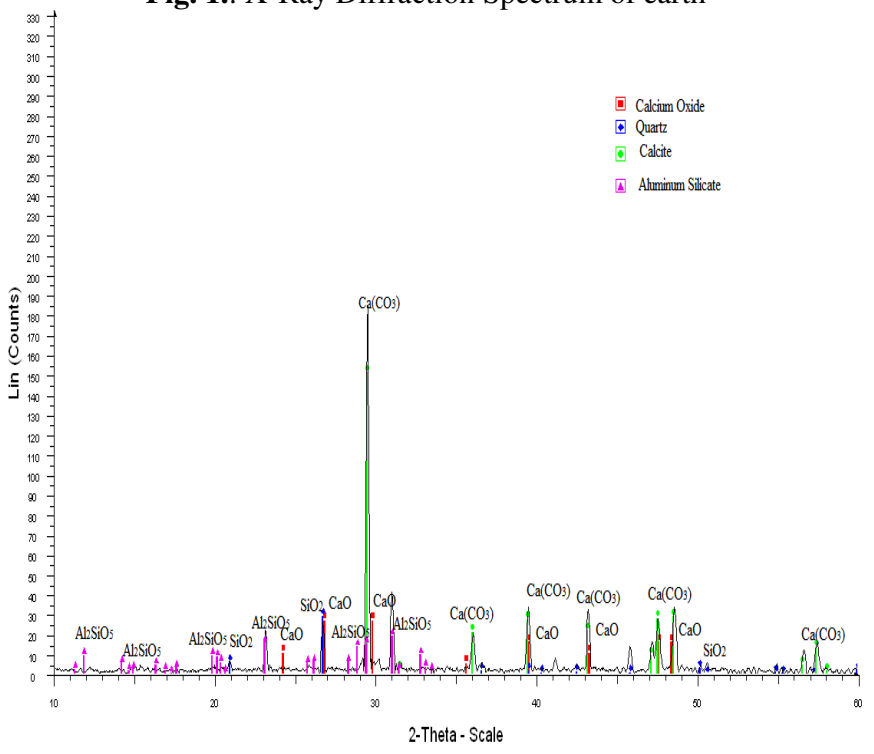

Figure.2. X-ray diffraction spectra at $4 \%$ cement 


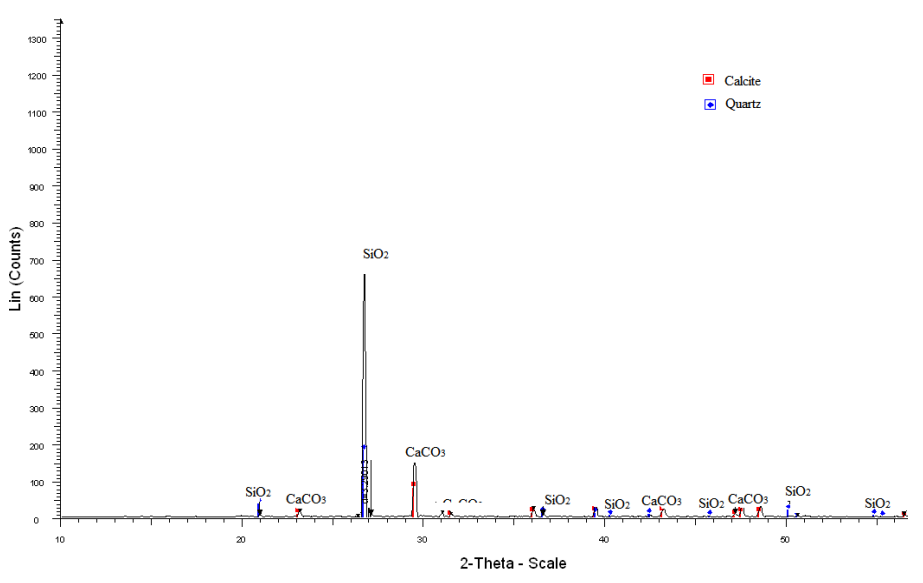

Figure 3. X-ray diffraction spectra at $7 \%$ cement

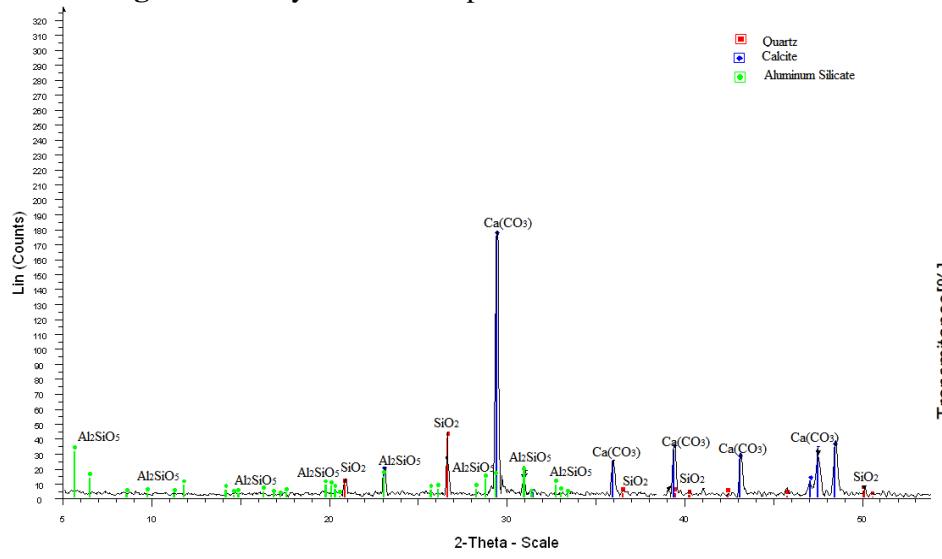

Figure 4. X-ray diffraction spectra at $10 \%$ cement

\subsection{Infrared Analysis}

Infrared analysis is a complementary method to X-ray diffraction analysis to study clays and clay minerals. The infrared spectra of the earth $\mathbf{F}$ and the specimens of the mortars of different cement dosages are shown in Figures 5, 6, 7 and 8. These spectra are strongly dominated by vibration bands of calcite $\mathrm{CaCO}_{3}$ (1798.1, 1431, 874, $712.6) \mathrm{cm}^{-1}$, of quartz at $(1033.5,798) \mathrm{cm}^{-1}$ and water at $\left(3416.1 \mathrm{~cm}^{-1}\right)$.

The formation of these carbonates is linked to the biophysical-chemical conditions of the earth. Whereas, the calcite is the product of the carbonation of lime, once mixed with water and sand, it has the property of rapidly setting by agglomerating inert particles, such as quartz [7, $8,3,9]$. We found bands of humic and fulvic acids that are linked to any root activity at $(2516.1,2876.3,530.5)$ $\mathrm{cm}^{-1} \cdot[7,8,3,9]$

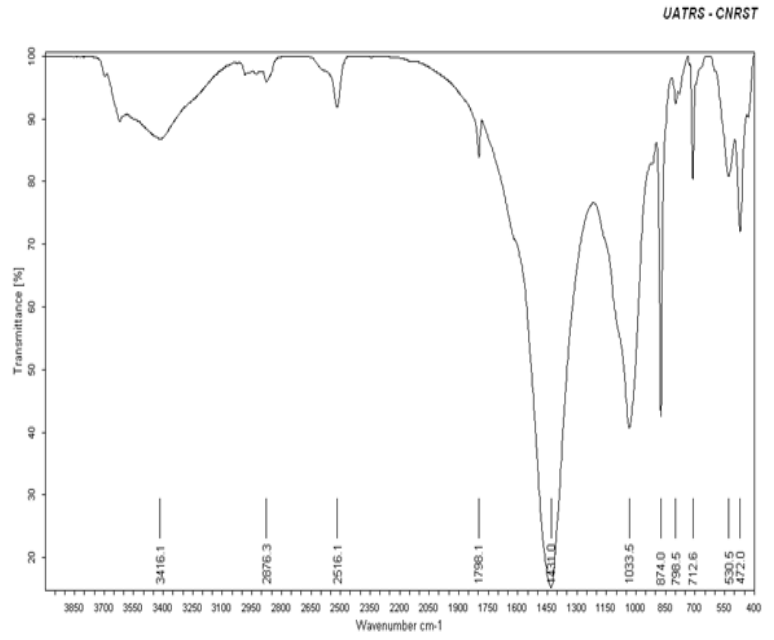

Figure 5. Infrared spectra of the earth of $\mathrm{F}$

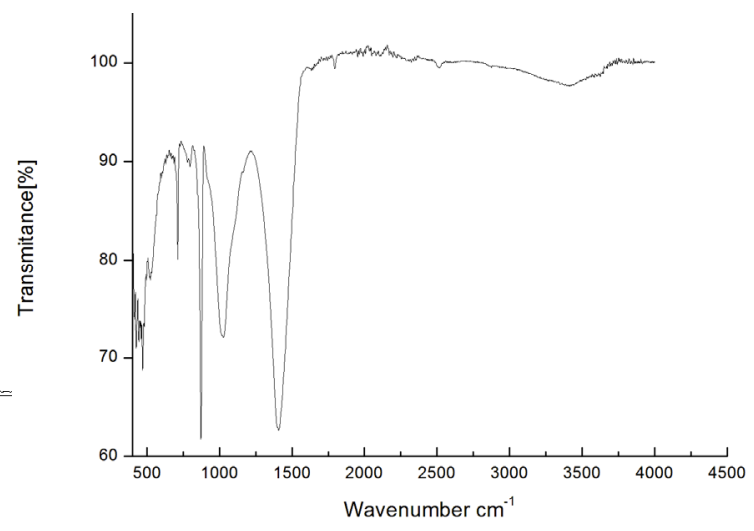

Figure 6. Infrared spectra with $4 \%$ cement

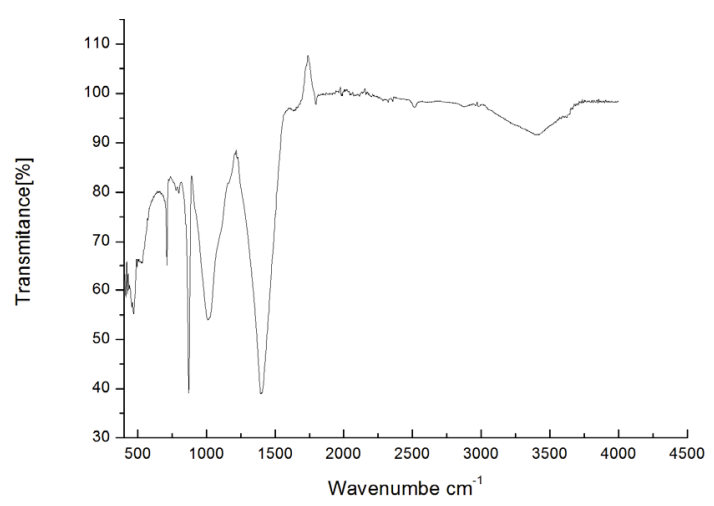

Figure 7. Infrared spectra with $7 \%$ cement 


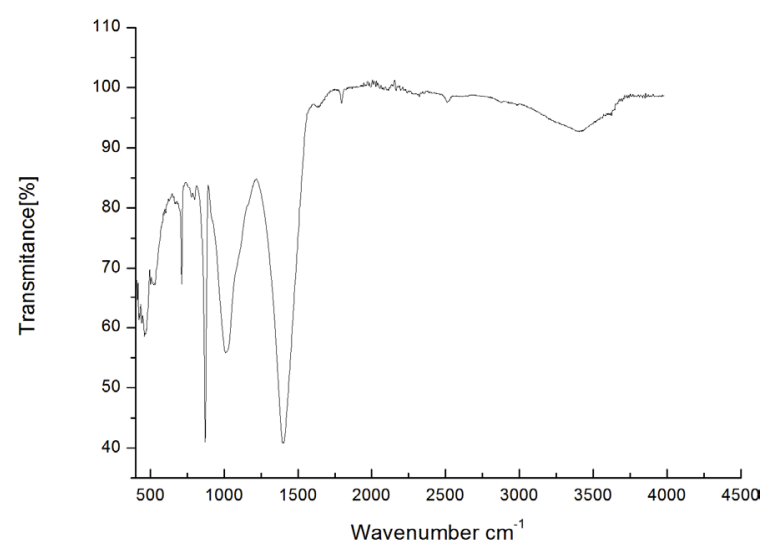

Figure 8. Infrared spectra with $10 \%$ cement

\subsection{Scanning Electron Microscope (SEM)}

SEM is a well-established method that can offer useful information concerning the structure of material. To better understand the evolution of the microstructure of earth samples.

From the images of earth $\mathbf{F}$ obtained by the SEM (Figure 9), we note that calcite is more dominant than quartz.

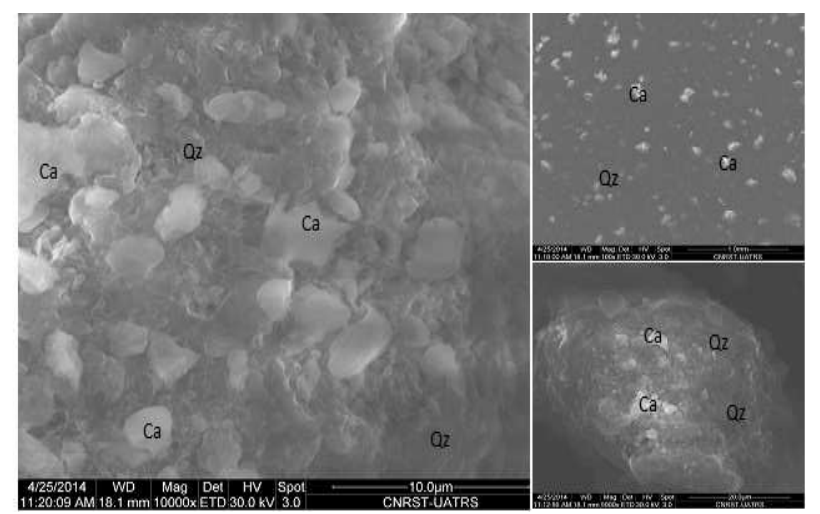

Figure 9. MEB images taken on the earth F (Qz: quartz, Ca: calcite)

\subsection{Analysis by fluorescence $X$}

The X-ray fluorescence analysis makes it possible to measure the percentage of chemical elements contained in the earth of sample F and the CPJ cement used in making the earthen mortar. Table 3 summarizes the rate of chemical elements:

Table .3. Chemical compositions of the land of Fez

\begin{tabular}{|c|c|c|}
\hline $\begin{array}{c}\text { Composition } \\
(\mathbf{\%})\end{array}$ & Earth F & $\begin{array}{c}\text { Cement CPJ } \\
\mathbf{3 5}\end{array}$ \\
\hline $\mathrm{SiO} 2$ & 22,3 & 12.46 \\
\hline $\mathrm{CaO}$ & 31,8 & 57.02 \\
\hline $\mathrm{Al} 2 \mathrm{O} 3$ & 5,96 & 3.39 \\
\hline $\mathrm{Fe} 2 \mathrm{O} 3$ & 1,72 & 1.89 \\
\hline $\mathrm{MgO}$ & 2,13 & 1.35 \\
\hline $\mathrm{SO} 3$ & 1,29 & 1.95 \\
\hline $\mathrm{K} 2 \mathrm{O}$ & 0,536 & 0.62 \\
\hline $\mathrm{TiO} 2$ & 0,226 & 0.18 \\
\hline $\mathrm{MnO}$ & 0,0503 & 0.03 \\
\hline $\mathrm{P} 2 \mathrm{O} 5$ & 0,753 & 0.11 \\
\hline
\end{tabular}

\begin{tabular}{|c|c|c|}
\hline $\mathrm{Na} 2 \mathrm{O}$ & 0,323 & -0.03 \\
\hline $\mathrm{SrO}$ & 0,0125 & 0.015 \\
\hline $\begin{array}{c}\text { PAF (perte au } \\
\text { feu à } 975^{\circ} \mathrm{C}\end{array}$ & 32,9 & 20.90 \\
\hline
\end{tabular}

There is an enrichment of $\mathrm{CaO}(31.8 \%)$ due to the presence of the matrix of carbonate and a high $\mathrm{SiO} 2$ content $(22,3 \%)$, due to the concentration of quartz. The losses on fire are to be linked with the presence of water.

\section{Experimental results}

\subsection{Test mode}

The tests are performed on cylindrical specimens in both wet and dry cases, height $\mathrm{h}=100 \mathrm{~mm}$ and diameter $\varnothing=$ $60 \mathrm{~mm}$.

First, we immerse the cylindrical specimens so that it is 5 $\mathrm{mm}$ below the water level (figure 10). A mortar's mass increases when immersed in water. It is said that the specimen has absorbed water. This increase in mass is due to the penetration of water into the cylinder through the pores. The water absorption represented by the coefficient $\mathrm{C}_{\mathrm{b}}$ characterizes the open porosity of a material. The crush test is performed by placing an antifrettage system composed of neoprene and Teflon between the two plates of the press and the test piece. This system allows better stress distribution thus leading to Homogeneity of applied forces of the cylindrical specimens of earthen mortar. The cement used in this study is CPJ 35 . The associated dosages are $0 \%, 4 \%, 7 \%$ and $10 \%$ by weight of cement.

Before the test, all specimens underwent a 28-day cure. The crushing speed is fixed at $10 \mathrm{~mm} / \mathrm{min}$.

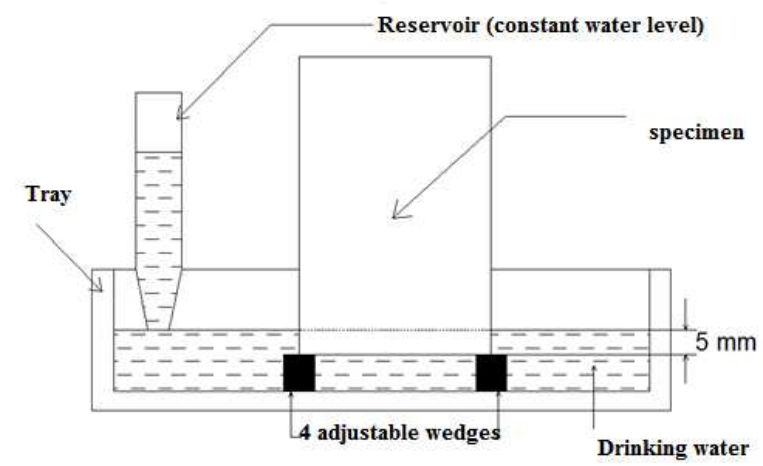

Figure.10. Schema of capillary absorption test

\subsection{Durability of mortar}

The following figure shows the variation of water absorption in relation to the cement content. 


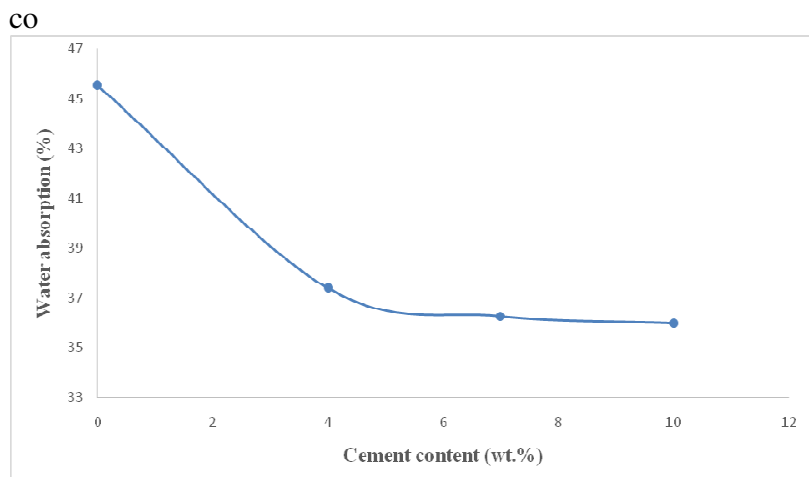

Figure 11. Water absorption coefficient as a function of the cement content

Figure 11 illustrates that the non stabilized specimens absorb a very large amount of water relative to the others which are stabilized. According to the specimens tested, the more cement content increases, the absorption of water by the specimens stabilized decreases. According to this test and to avoid capillary action, if we add a dosage of cement between $4 \%$ and $7 \%$ with respect to the dry mass of the earth it is sufficient to prevent the absorption of water. The addition beyond [4\%- 7\%] does not result in any significant gain $[4,14,20]$.

\subsection{Mechanical Results and Interpretations}

The figures.12, 13 and 14 show the gain evolutionof the compressive strength, modulus of elasticity and deformation limit of the test specimens of mortar the earth $\mathbf{F}$ in both cases (dry and wet).

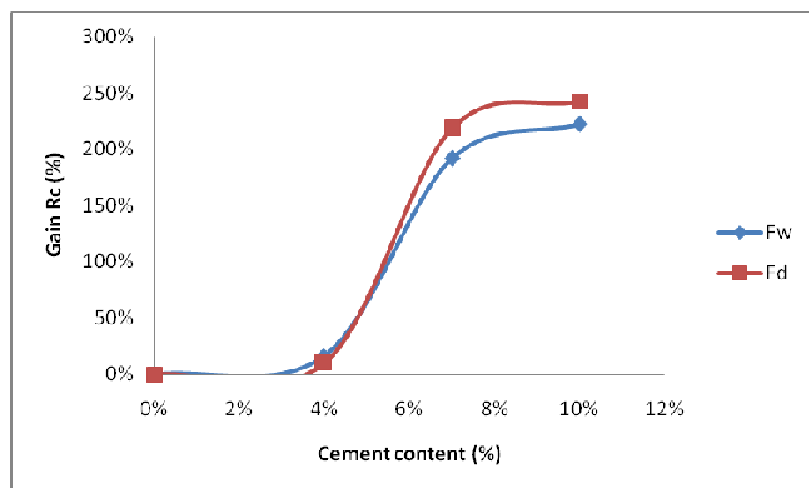

Figure 12. Gain of the compressive strength of the dry mortar F $(\mathrm{Fd})$ and wet $(\mathrm{Fw})$ as a function of the cement dosage

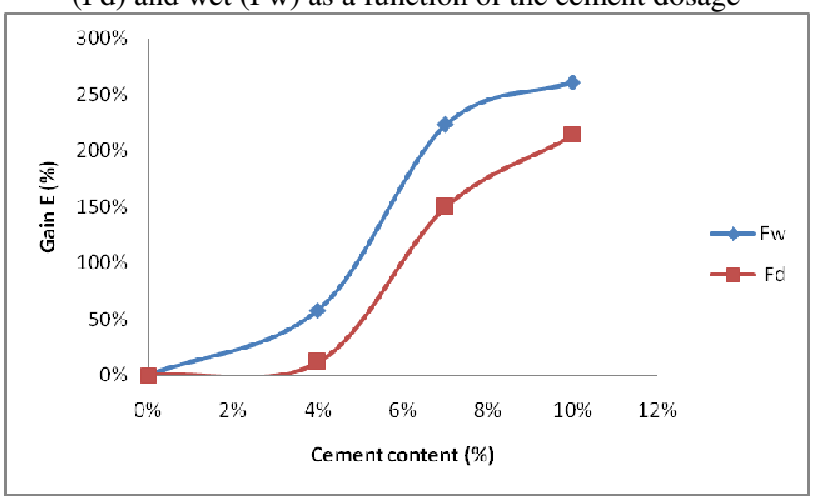

Figure 13. Gain of modulus of elasticity of the mortar F dry $(\mathrm{Fd})$ and wet $(\mathrm{Fw})$ depending on the dosage

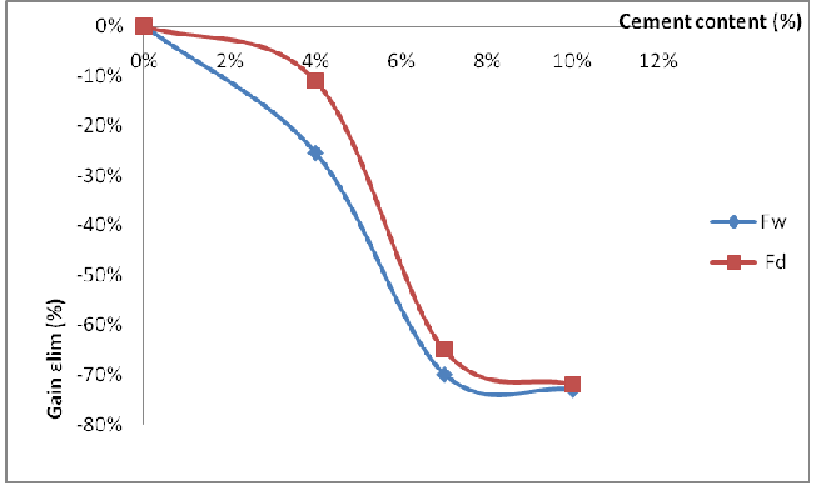

Figure 14. Limit deformation of wet( $\mathrm{Fw})$ and dry mortar $(\mathrm{Fd})$ as a function of the dosage

Figure 12 shows that the compressive strength of the earth $\mathbf{F}$ increases according to the cement content rate. All recent studies [9, 3, 6, 10, 11, 12, 13, 21, 22] have shown that the mechanical properties increase with the cement dosage without giving the function of this increase. Since this increase is varied according to the particle size and the mineralogical composition of the earth, which impacts the economic investment in cement. There is an increase of the compressive strength gains and the elasticity module according cement content in the dry state of the earth $\mathbf{F}$. The percentage, the gain evolution of the compressive strength is irregular: When passing from 0 to $4 \%$ of cement dosage it is of the order of $10 \%$, when one passes from 4 to $7 \%$ it of the order of $219 \%$ and when one passes from 7 to $10 \%$ it is of the order of $243 \%$. The same gain evolution is noted for the modulus of elasticity, but this gain in the wet state is high compared to the dry state.

We also note that the limit strain decreases when the cement content increases. In terms of the percentage, the deformation decreases by $-11 \%$ when passing from 0 to $4 \%$ of the dosage, and $-65 \%$ when passing from 4 to $7 \%$, and decreases by $-72 \%$ when passing from 7 to $10 \%$ of the cement. This comparison shows an increase in the gain of the compressive strength and the modulus of elasticity gain as a function of the wet cement dosage of the same earth $\mathbf{F}$. In terms of percentage, the evolution of the resistance in compression is irregular: when one passes from 0 to $4 \%$ of cement dosage it is of the order of $16 \%$, when one passes from 4 to $7 \%$ it of the order of $192 \%$ and when it goes from 7 to $10 \%$ it is of the order of $222 \%$. We notice almost the same evolution for the modulus of elasticity. It is also observed that the limiting deformation decreases when the cement dosage increases. In terms of percentage gain, deformation decreases by $25 \%$ when passing from 0 to $4 \%$ of the assay, and $-70 \%$ when passing from 4 to $7 \%$, and decreases by $-73 \% 7$ to $10 \%$ of the cement.

The mineralogical results show that the clay of the earth F and their mortar specimens of the different cement dosages are formed mainly of quicklime $\mathrm{CaO}$ and quartz $\mathrm{SiO}_{2}$, which favors the stabilization of the clay by the reaction of quicklime and water. Although the quartz is not a binder, it is constituted by a portion of the fraction of fine sand $[16,17,18,7]$. The quartz grains of this earth are cemented by the carbonation of the lime.

The addition of low cement content is insufficient to stabilize the sand fraction of this earth, which gives us a 
small variation in compressive strength from $0 \%$ to $4 \%$ cement in the both cases dry and wet. It is only when the cement dosage increases to $4 \%$ that the value of the compressive strength increases and is equal to $0.100 \mathrm{MPa}$ for the dry state and $0.057 \mathrm{MPa}$ for the wet state. We found that for $7 \%$ cement in that earth the silicoaluminous is absorbed (Figure 3 ), by reacting to calcium hydroxide to form a compound having binding properties. Therefore, all the links are already created, giving a very high compressive strength. On another layer, the hydrated cement matrix reacts in two ways [16]: a strong reaction with the sandy skeleton and a very weak reaction with the clay which is already stabilized by its chemical constituents to improve the compressive strength of mortar specimens.

\section{Conclusion}

The mineralogical analysis of the earth of Fez and their mortar shows that it consists mainly of calcite, quartz and dolomite with different proportions.

The chemical analysis carried out on the earth of $\mathrm{Fez}$ show an enrichment of $\mathrm{CaO}(31,8 \%)$ linked to the abundant presence of the carbonate matrix, and a content of $\mathrm{SiO}_{2}(22,3 \%)$, due to the concentration of quartz.

The matrix in the soil is essentially represented by calcite. The mechanical behavior of the earthen mortar is strongly influenced by the cement dosage employed, the mineralogy and the chemistry of the earth.

The strength gain and modulus of elasticity improve while increasing the rate of cement dosing. However, the gain of the limiting deformation evolves in the opposite direction. Concerning the capillary rise, water absorption decreases with addition of the cement. We also note that the evolution of the mechanical characteristics does not matter that in the interval [ 4 at $7 \%$ ] which represents the area of effect for cement stabilization; consequently, the technico-economic optimum for stabilization will be located in this area $[4 \%, 7 \%]$.

\section{References}

1. S.L. Pagliolico, S. Ronchetti , E.A. Turcato, G. Bottino, L.M. Gallo, R. DePaolia, (2010)

2. Y. Millogo , M. Hajjaji b, J.C. Morel, Applied Clay Science 52 (2011)

3. Younoussa Millogo, Mohamed Hajjaji , Raguilnaba Ouedraogo, Construction and Building Materials 22(2008)

4. Bouabid H., Thèse de Doctorat d'Etat, Université Mohamed V. Rabat. Juillet (2000).

5. A. Guettala , A. Abibsi , H. Houari, Construction and Building Materials 20 (2006).

6. R. Bahar, M. Benazzoug, S. Kenai b, Cement \& Concrete Composites 26 (2004).

7. Abdelilah Dekayir, Marc Amouric, Juan Olives, Claude Parron, Abdelilah Nadiri, Abdelkader Chergui, M. Abdeljalil El Hajraoui,. C. R. Géoscience 336 (2004)

8. F. Gouny, F. Fouchal , P. Maillard, S. Rossignol, Construction and Building Materials 36 (2012).

9. Younoussa Millogo, Jean-Claude Morel ; Materials and Structures 45 (2012)
10. Philip Zak, TahaAshour, AzraKorjenic, Sinan Korjenic, Wei Wu.,Construction and Building Materials. 106 (2016)

11. P. J. Walker., Cemenf \& Concrete Composites 17 (1995)

12. Peter Walker, trevvr Stace., Materials and structure/Matériaux et construction .30(1997)

13. C. Jayasinghe, N. Kamaladasa, Construction and Building Materials 21 (2007)

14. H.B. Nagaraj, M.V. Sravan, T.G. Arun, K.S. Jagadish., International Journal of Sustainable Built Environment 3 (2014)

15. Bell. F. G., Eng. Geol. 42(4) (1996)

16. A. Ammari, K. Bouassria, A. Tayyibi, H. Bouabid, M. Cherraj, S. Charif d'Ouazzane, M. Ibnoussina., J. Mater. Environ. Sci. 7 (10) (2016)

17. K. Bouassria, A. Ammari, A. Tayyibi, H. Bouabid, J. Zerouaoui, M. Cherraj, S. Charif d'Ouazzane., J. Mater. Environ. Sci. 6 (12) (2015)

18. Mertens G., Elsen J., Laduron D., Brul R., Revue d'archéométrie. 30 (2006).

19. Bachir Taallah, Abdelhamid Guettala, Construction and Building Materials 104 (2016)

20. M. Cherraj, K. Gueraoui, H. Bouabid, S. Charif d'Ouazzane, R. Bouabid , A. Hammoumi , O FassiFehri., Phys. Chem. News 42 (2008).

21. A. Ammari, K. Bouassria, M. Cherraj, H. Bouabid, S. Charif D'ouazzane, Case Studies in Construction Materials 7 (2017)

22. O. Izemmourena, A. Guettala MATEC Web of Conferences 11,02001 (2014) 